\title{
Herminio, sempre amigo
}

\author{
Miguel PÉREZ PEREIRA \\ Universidade de Santiago de Compostela
}

Herminio foi unha persoa pola que teño un afecto especial. Aínda que morreu, o afecto segue, se ben mesturado con dor polas ocasións perdidas de termos falado e compartido máis a vida. Rememorando a Gamoneda, o poeta da melancolía, el dicía que facer memoria é ter conciencia da perda, e, xa que logo, sufrimento. Nada máis certo lembrando a Herminio, un ser absolutamente entrañable, a quen era tan doado querer.

Coñecín a Herminio á miña chegada á antiga Facultade de Filosofía e Ciencias da Educación da Universidade de Santiago de Compostela no mes de abril de 1977. Eu era, daquela, militante do Partido Comunista, e un dos fundadores de CCOO do ensino en Vigo. O meu primeiro encontro foi no claustro do caduco edificio de Fonseca, ao carón das centenarias azaleas, onde provisoriamente estaba a facultade, un edificio daquela cheo de goteiras e onde a calefacción daba para pasar frío, pero algo menos que na rúa. Presentáronmo xunto a outros colegas, entre os que estaban Luís Villegas, Xoán Pintos, Antón Costa (a quen eu xa coñecía do movemento da escola popular), ou José Luís González. A acollida de Herminio foi extraordinaria pola calidez, unha das súas características persoais máis salientables.

Como eramos camaradas, coincidíamos en reunións do PC e do Sindicato, pero tamén tiñamos tempo para tomarmos os viños xuntos e compartir algún que outro xantar. Herminio destacaba pola súa capacidade de comprensión das posicións dos outros e esa perspectiva que lle permitía ía máis alá, coma se tivese unha guía que lle facía ver as cousas nunha dimensión case que atemporal. A revolución non era cousa dun día, e o camiño do progreso, sinuoso.

Aínda que non gustaba de protagonismos nin de ocupar cargos ou responsabilidades, el sempre asistía ás reunións do sindicato con entrañables compañeiros como Miguel Fonseca, particularmente nas épocas de reforma democrática da Universidade, na que semellaba que o papel dos sindicatos, concibidos como de carácter sociopolítico, tamén podía ser importante. Esa época da transición política era algo especial. Todo estaba bastante aberto, e case calquera cousa era posible, de aí que as ilusións foran moito maiores do que poden ser hoxe, unha época certamente difícil e na que, nos países occidentais cando menos, é difícil mover o estado das cousas.

Unha característica del era a de non ser un home conflitivo. Era un home tranquilo que tiña a difícil virtude de buscar os puntos de consenso e o que unía, máis que as discrepan- 
cias. Probablemente porque tiña esa ollada de futuro, que facía que non se arredara dos obxectivos últimos.

Herminio tiña unha inconmovible fe no futuro, no progreso da humanidade cara a unha sociedade máis xusta e igualitaria, e foi quen de manter esa fe mesmo en épocas difíciles. Lembro, por exemplo a época da renuncia do Partido Comunista aos símbolos da República (a bandeira republicana) e a aceptación da monarquía constitucional. Para Herminio, unha persoa criada nunha familia de fondas crenzas republicanas, e el mesmo firme admirador dos valores e das prácticas da República, tivo que ser moi difícil que a política da esquerda sociolóxica deixara á marxe a recuperación da tradición republicana, e a República quedara fóra da axenda política, ou, cando menos, se adiara sine die.

A súa actividade profesional como pedagogo centrouse moito tamén en rescatar figuras senlleiras da, vista en perspectiva, monumental reforma educativa republicana, como Lorenzo Luzuriaga, e as revolucionarias experiencias que desde o ano 1931 ata a caída da República (mesmo durante o transcurso da Guerra Civil) tiveron lugar no Estado español. Era moi consciente do extraordinario papel que os mestres e profesores estaban xogando na transformación da vida social e dos individuos durante a República, e por iso, e porque o viviu ben de preto co seu pai, doíalle aínda máis a terrible persecución que sufriron co franquismo. 0 maxisterio foi un dos estamentos cos que máis se asañaron as autoridades da Ditadura que pronto se decataron do papel que xogaran no extraordinario intento de transformación social republicana. Era preciso arrasar todo indicio desa época. No seu libro Recordar doe, contrapón de forma vívida e sentida os valores e prácticas da escola franquista cos da escola republicana.

Foi a de Herminio Barreiro unha xeración recia que trazou o suco da liberdade e a loita social ás seguintes xeracións, e fixérono, tanto na súa vertente nacionalista como comunista, creando novos obxectivos e formas de loita. Pero tamén é certo que o fixeron a golpes. Aínda lembro como no curso 1968-1969 o meu profesor de literatura de preu do instituto Santa Irene de Vigo Xosé Luís Méndez Ferrín, e bo amigo de Herminio desde os seus tempos do colectivo Brais Pinto en Madrid, foi detido e encadeado polo réxime franquista durante varios meses. 0 propio Herminio tamén visitou a sombra entre reixas nalgunhas ocasións, aínda que por períodos máis curtos.

Discreto como era, tardei tempo en saber, por el, de que tiñamos unha relación de parentesco. El sabía ben das miñas orixes, porque unha miña irmá estaba casada con Carlos Amable Baliñas, e logo púidome relacionar ben coa miña familia. Unha familia que era dunha tradición ben diferente da de Herminio, de pais republicanos que sufriron a represión do franquismo. El fora compañeiro no instituto de Pontevedra do meu irmán Félix (desgraciadamente tamén falecido, e do que Herminio aínda gardaba unha foto na que estaban xogando con outros amigos ao fútbol na Lanzada), e sabía que tiñamos curmáns (en segundo ou terceiro grao) comúns: os Gómez de Raxó, de onde era a miña nai. Moitos deles xa fillos da emigración que, á súa vez, tiveron tamén que buscarse a vida na miserenta e triste España franquista fóra de Galicia, como Faustino, Constantino, ou Heraclio, 
que chegou a ser almirante da armada dos Estados Unidos de Norteamérica, e co que Herminio seguiu tendo relación.

Decateime tamén co tempo de como Herminio gustaba de coidar e cultivar o seu contorno familiar e vital. 0 delicado e agarimoso recordo dos vellos amigos, dos que nalgún tempo significaron algo na súa vida, dos seus parentes. É como se se negara a que caeran no esquecemento. Recodándoos facíaos presentes e rescatábaos da escuridade do esquecemento, dándolle tamén sentido á súa vida. Un non é só o que é no momento actual, senon tamén o que foi; algo bastante afastado dos parámetros actuais da existencia do ser humano, que semella ser atemporal, sen raiceiras e ahistórico. Esa perspectiva histórica, consonte coa súa actividade profesional como historiador da educación, foi tamén algo moi característico do extraordinario ser humano que foi Herminio.

Tiña fe no progreso da humanidade, como dicía a súa necrolóxica. Un pouco por ese optimismo do materialismo histórico, pero tamén pola súa visión do ser humano com esencialmente bo, tan propia do seu admirado Rousseau. Nestes tempos de absurda crise e desesperanza no futuro precisamos da súa fe. 